\title{
INVESTIGATING INSTRUCTIONAL DESIGN SKILL DEVELOPMENT DURING THE PROJECT BASED MULTIMEDIA DEVELOPMENT PROCESS
}

\author{
Türkan KARAKUŞ YILMAZ \\ Atatürk Üniversitesi, Kazım Karabekir Eğitim Fakültesi, Erzurum, Türkiye \\ turkan.karakus@gmail.com \\ Kürşat ÇAĞILTAY \\ Orta Doğu Teknik Üniversitesi, Eğitim Fakültesi, Ankara, Türkiye
}

\begin{abstract}
While instructional design is a fast growing, changing and improving field, instructional designer training requires multi-faceted, real life-like, process oriented and contemporary educational understanding. In this case study, the learning outcomes obtained by the junior students who study at Computer Education and Instructional Technology and took a multimedia development course consisting an intense design process were investigated. During a semester, strategy of creating a team, nature of the projects and facilitators were changed for each project in the design course consisting two projects. While the actual participants of the study were 47 students (novice instructional designers), 16 graduates and 10 previous year students were interviewed to triangulate the results. To measure learning outcomes of current students, a survey was implemented as a pre and posttest. Project team and individual interviews were analyzed through content analysis. According to survey results, current students showed a significant improvement in skills on knowledge of instructional technologies, conducting instructional design processes, development of storyboards, using multimedia development programs, assessing instructional materials, using technological resources for instruction effectively, conducting and reporting research, editing audio/video, working collaboratively in teamwork and hardware knowledge. Regarding the entire data gathered from the all participants of the study, apart from survey results, they stated that they got a real life experience and learn how to communicate with target learners. The results imply that students are able to get many skills accepted as instructional designer skills in instructional design field via a multimedia design course. However, during the course, students had some problems such as lack of setting a connection between instructional design phases because of time limitations, challenging to contact with a real target group and having negative influences in processes and end products because of instructor-led random assignment of the first project teams. The results of the study will offer a resources for the future courses in terms of elaborating the outcomes brought by multimedia design process as well as the issues influencing the outcomes.
\end{abstract}

Keywords: instructional design course, novice instructional designers, multimedia design and development, learning outcomes

\section{PROJE TABANLI ÇOKLU ORTAM TASARIMI SÜRECINDE ÖĞRETIM TASARIMI BECERILERININ GELIŞIMININ ARAȘTIRILMASI}

ÖZ
Öğretim tasarımı, hızla büyüyen, değişen ve gelişen bir alan olup, öğretim tasarımcılarının eğitimi de
çok yönlü, gerçek hayatla uyumlu, sürece odaklı ve güncel bir eğitim anlayışı gerekmektedir. Bu
durum çalışmasında, yoğun bir tasarım süreci içeren çoklu ortam tasarımı dersini alan, Bilgisayar ve 
Öğretim Teknolojileri Eğitimi bölümü 3. Sınıf öğrencilerinin, öğretim tasarımı alanı ile ilgili elde ettikleri kazanımlar incelenmiştir. Bir öğretim dönemi boyunca, iki projeyi kapsayan tasarım dersinde her iki projede takım oluşturma stratejisi, projenin doğası, danışmanlar gibi unsurlar değişmiştir. Çalışmanın asıl katılımcılarını dersi alan 47 öğrenci (acemi öğretim tasarımcıları) oluştururken, 16 mezun ve 10 bir önceki yıldan aynı dersi alan öğrenci ile de sonuçların teyit edilmesi adına görüşmeler yapılmıştır. Çalışmada mevcut öğrencilerin öğrenme çıktılarını ölçmek için ön ve son test şeklinde uygulanan bir anket kullanılmıştır. Proje grupları ile yapılan görüşmeler ve bireysel görüşmeler ise içerik analizi yöntemiyle analiz edilmiştir. Anket sonuçlarına göre mevcut öğrenciler öğretim teknolojileri konusunda bilgi sahibi olma, öğretim tasarım süreci yürütme, öykü yaprakları oluşturma, çoklu ortam tasarım programları kullanma, öğretim materyallerini değerlendirme, öğretim teknolojilerini etkin şekilde öğretim için kullanma, araştırma ve raporlama, ses video işleme, takım çalışması ve donanım bilgisi gibi unsurlarda anlamlı ölçüde yetkinlik kazandıkları görülmüştür. Tüm katılımcıların görüşmelerinden elde edilen sonuçlara göre ise, anket sonuçlarından farklı olarak, katılımcılar gerçek yaşam deneyimi kazandıkları ve hedef kitle ile iletişim kurmayı öğrendiklerini belirtmişlerdir. Çalışmanın sonuçları, öğrencilerin öğretim tasarımı alanında kabul edilegelen öğretim tasarımcısı becerilerinin bir çoğunu çoklu ortam tasarımı sürecinde elde edebildiklerini göstermektedir. Ancak bu süreçte, öğrencilerin zamanın kısıtlllığ nedeniyle sürecin yeterince anlaşılmaması, gerçek bir hedef kitle ile iletişime geçmenin zorluğu, öğretim üyesi tarafindan belirlenen bir takımla çalışmanın proje performans ve ürününü etkilemesi gibi sorunların da yaşandığı belirlenmiştir. Çalışmanın sonuçları çoklu ortam tasarımının getirdiği kazanımların yanısıra, bunları etkileyen unsurları da irdelemesi yönüyle de yeni oluşturulacak dersler için bir kaynak sunmuş olacaktır.

Anahtar kelimeler: ögretim tasarım dersi, acemi ögrretim tasarımcıları, çoklu ortam tasarım ve geliştirme, ögrenme kazanımları

\section{INTRODUCTION}

Instructional design and technology (IDT) is a field which "encompasses the analysis of learning and performance problems, and the design, development, implementation, evaluation and management of instructional and non-instructional processes and resources intended to improve learning and performance in a variety of settings, particularly educational institutions and the workplace" (Reiser, 2001, p. 53). Although IDT's available definitions are very broad, this definition continuously changes in definition and scope, as IDT field renovates and changes (Reiser, 2007). Expected competencies of instructional designers have also been changed (Davidson-Shivers \& Rasmussen, 2002). This change brings new approaches and strategies to train NIDs in accordance with the needs of the field.

Instructional designers learn in a flexible and self-directed environment, which is also the assumption of constructivist philosophy. To train instructional designers, especially project based and design based authentic activities where the designers get insights from different contexts are used (DavidsonShivers \& Rasmussen, 2002). Since they learn by designing, also a constructionist perspective (Papert \& Harel, 1991) is applied in instructional design projects. Both constructivism and constructionism pose that the truth is not dictated by the world; acquisition of knowledge is influenced by their social life and other different activities that they engage (Gergen, 1985). These two views assume that the artifact of the "communal interchange" is the source of the understanding the world as stated by Gergen. The context is very important to understand the world since all the actions and activities are embedded in a social context (Young \& Collin, 2004). Therefore, it can be argued that instructional design environments should accommodate the methods which take the context into consideration.

Competencies of instructional designers have been defined by different associations which are related to instructional design. The most reputable one, the IBSTPI (Spector, 2001) defines some of the competencies as communication, application of research and theory of practice, analysis of processes and all elements of instruction, design and development by selecting suitable medium, strategies and materials, implementation, and evaluation of all processes (Davidson-Shivers \& Rasmussen, 2002). 
Although there are varieties of descriptions of instructional designer competencies, the curriculum of IDT field still needs authentic assessment systems to certify the instructional designers. In the light of competency definitions, evaluation criteria for academic programs can be developed to guide the development of curricula and content of the courses, to provide a self-assessment for practitioners to assess their skills and knowledge (Bratton, 2007). In assessment the issue of to what extent context influence the teaching should also be taken into consideration (Bannan-Ritland, 2001). In this sense, to assess the outcomes and performance of instructional designer education environments, contextual factors should be examined.

The researcher of this study has several years of experience with guiding Novice Instructional Designers (NIDs). At the department of Computer Education and Instructional Technology (CEIT), junior students take a multimedia design and development course which aims to give experience of instructional design via real life practice. The students of the course are involved in two intensive multimedia design and development projects, by working in teams under the guidance of course facilitators. They work with real clients and they communicate with them during the project. Students follow a specific instructional design process which includes analysis, design, development, implementation and evaluation. In the first project, the project groups are assigned by the instructor and in the second they choose their group members. During the project they have different roles. Since they are junior students they are assumed to have enough background to manage a project and design a product. The course has both theoretical and practical applications. The instructional design process has been given to students with an authentic and real life - like experience. Five years of experience of the researcher has shown that, students have variety of issues, problems and motivations during the semester that the course is given.

\section{COMPETENCY DEFINITIONS AND TRAINING OF INSTRUCTIONAL DESIGNERS}

As cited in Spector (2001), The International Board of Standards for Training, Performance and Instruction (IBSTPI) defines competency as "a knowledge, skill, or attitude that enables to effectively perform the activities of a given occupation or function to the standards expected in employment" ( $\mathrm{p}$. 180). Since the performance based educational techniques was born, expected learner competencies started to shape the design and development of the programs (Richey, Fields \& Foxon, 2001). Besides, competency definitions are very helpful to design the courses and student assessment according to Richey et al (2001). They point out that role definitions of real settings might be used to define the competencies. Competency definitions for instructional design and technology field will assist to design instructional design courses and define assessment criteria for novice instructional designers.

Gustafson (2002) and AECT 2000 (as cited in Rasmussen, 2002) suggest instructional design competencies as instructional design (flexible design), performance improvement planning, effective communication, research, and computer based skills. After a longitudinal validation process, in 2000, IBSTPI revealed 23 core competencies of instructional designers (Richey, et al, 2001). Those competencies were summarized in Table 1.

Table 1 ID domains and competencies defined by IBSTPI (Richey et al, 2001, pp. 46-55)

1. Communicate effectively in visual, oral and written form. (Essential)

2. Apply current research and theory to the practice of instructional design. (Advanced)

Professional 3. Update and improve one's knowledge, skills and attitudes Foundations pertaining to instructional design and related fields. (Essential)

4. Apply fundamental research skills to instructional design projects. (Advanced)

5. Identify and resolve ethical and legal implications of design in the work place. (Advanced)

6. Conduct a needs assessment. (Essential)

7. Design a curriculum or program. (Essential)

Planning and

8. Select and use a variety of techniques for determining

Analysis instructional content. (Essential) 
9. Identify and describe target population characteristics. (Essential)

10. Analyze the characteristics of the environment. (Essential)

11. Analyze the characteristics of existing and emerging technologies and their use in an instructional environment. (Essential)

12. Reflect upon the elements of a situation before finalizing design solutions and strategies.(Essential)

13. Select, modify, or create a design and development model appropriate for a given project.(Advanced)

14. Select and use a variety of techniques to define and sequence the instructional content and strategies. (Essential)

Design and Development

Implementation and Management
15. Select or modify existing instructional materials. (Essential)

16. Develop instructional materials. (Essential)

17. Design instruction that reflects an understanding of the diversity of learners and groups of learners. (Essential)

18. Evaluate and assess instruction and its impact. (Essential)

19. Plan and manage instructional design projects. (Advanced)

20. Promote collaboration, partnerships and relationships among the participants in a design project. (Advanced)

21. Apply business skills to managing instructional design. (Advanced)

22. Design instructional management systems. (Advanced)

23. Provide for the effective implementation of instructional products and programs. (Essential)

The competencies listed in Table 1 were also taken as base of the outcomes of the course in that the study was conducted. Apart from IBSTPI there are several research to reveal the required competencies of instructional designers. To reveal the competencies of instructional designers, comparison between novice and expert designers take important place in instructional technology and design research. In one of the study to reveal expert designers' competencies, be taken into consideration to meet the needs of real settings where instructional designers work.

Today, to give complex instructional design skills, mostly case studies, project based approach, cognitive apprenticeship and collaborative group activities are used in ID education (Jonassen RohrerMurphy, 1999; Bannan-Ritland, 2001; Visscher-Voerman et al. 2007; Yusop and Correia 2012). While educating instructional designers, use of contextual and constructivist approaches such as apprenticeship, practicing, professional real life experience, experience of contextualized knowledge is also suggested (Winn, 1997). Bannan-Ritland (2001) believes that instructional design and technology competencies can be given by using real world experiences in a challenging context. Therefore, this study, internalize a contextual approach for analysis of an instructional design course in terms of providing enough experiences to provide required instructional design competencies. Rowland, Parra and Basnet (1995) also reported that presentation of concepts and procedures, simple examples, exercises of instructional design and some small projects are used in training programs frequently. However, Rowland et al believe that for IDT education, iterative and cyclical processes and situations which require generative and creative skills, studio approach and competitive environment should be created. Bannan-Ritland (2001) also admits that even all those advance techniques are not enough unless they are brought out from strict college courses. Seels (1995) points out that IDT programs have very few courses which require to work out of the college. Additionally, she suggests that academic programs should be organized to make students develop their profession by means of socialized applications in these programs. Seels (1995) suggests trainers to create exemplary activities to provide behaviorally, emotionally and intellectually adaption to the field. Moreover, to use the ID skills in different problem situations, the ID practitioners should experience to as much as different contexts (Tessmer \& Richey, 1997). 


\section{MULTIMEDIA DESIGN AS A CONTEXT OF TRAINING INSTRUCTIONAL DESIGNERS}

Multimedia is defined as "a class of computer-driven interactive communications systems which create, store, transmit, and retrieve textual, graphic, and auditory networks of information" (Gayeski, 1993, p. 4). Multimedia design and development which is the context of this study, has several opportunities to make novice instructional designers acquires some skills and competencies of the field oif IDT. As a design based learning environment, by means of multimedia design technical skills (Kafai, 1995), collaborative working skills (Gifford \& Enyedy, 1999) and knowledge of subject matter (Kafai, 1995; Barron et al. 1998) can be obtained. Hardre, Ge and Thomas (2006)'s case study showed that when a novice instructional designer designs a learning material, they might get more selfawareness, self-monitoring skills, clear understanding of IDT practices. Besides, novices might understand the expected competencies and learn how to improve their current knowledge to reach the goals of the field.

In IDT education, media design provides novice instructional designers to follow different ID models, to create solutions, to develop technical skills, to examine real life contexts and to interact with the target group (Rowland, et al., 1995). Novice instructional designers can make collaboration with target group (teachers or learners) to develop resources which meet target group's needs effectively. Sugar (2001) argues that most of technology-rich training systems have problem of lack of collaboration with end-users. He suggests IDT practice to have iterative system which including an administrative system, a project team, an effective involvement and communication system. Therefore, IDT practices should include activities to provide collaboration with real learner community, team members and administrative system.

Liu and Rutledge (1996)'s study showed that multimedia design provides motivation and involvement, self-efficacy, brainstorming, teamwork skills, learning multimedia tools and researching skills. The study conducted by Sherry and Myers (1998) related with design of web page of a university revealed that there is a relationship between learning and design. They concluded that "... whenever a product emerges from the design and development process, as opposed to being constructed from a predefined blueprint, designing will require development of new skills and concurrent knowledge with the carrying out of design tasks."(p.129). This conclusion shows that, multimedia design reveals lots of knowledge resources, because design process requires several viewpoints and solutions for many problems. In this process, it is expected that both participants and designers have a chance to learn about development of the product.

In IDT education, design is assumed as a problem solving process (York, Ertmer \& Gedik, 2009; Tracey \& Baaki, 2014). The way that instructional designers solve ID problems and apply the knowledge, the processes they go through, the goals they established and their management, monitoring and evaluation processes are the indicators of how the instructional designer promote their instructional design (Gustafson \& Branch, 2007). Multimedia design which is an immersion strategy provides instructional designers an ill structured problem that makes novice instructional designers solve a problem collaboratively (Dabbagh \& Blijd, 2010). All the collaborators generate a solution and knowledge base via dialogue, interaction and collaboration (Dabbagh \& Bannan-Ritland, 2005). The study of York et al (2009) showed that while solving a problem an expert instructional designer use the heuristics composed of "communication, management, learner/audience, solutions, deliverables, outcomes, design process, design team, design problem, and client" (p. 499). In conclusion, they pose several questions to answer whether the novice instructional designers can be taught to be an expert instructional designer, what methods and strategies in IDT programs could present for novice instructional designers to give these heuristics, and what would be the impact of these methods and strategies.

\section{METHOD}

\section{PARTICIPANTS OF THE STUDY}

Main participants of the study were 47 undergraduate junior students (33 males and 14 females) who were studying at the Department of Computer Education and Instructional Technology. The current 
students were enrolled in the mandatory "Multimedia Design and Development" course which was known as "Instructional Technologies and Material Development" in previous years. After conducting a pilot study with senior students who were enrolled in a game design course which also aims to teach an instructional design process via development of a game, the researcher decided to work with students who have no practical experience with an instructional design process. Although these students get some courses related to design and development of computer based products, the main purposes were to teach the design of the materials and screen design issues rather than the instructional design process. The junior students have some technical skills like programming, web authoring, and screen design.

Students formed groups and observations conducted on those groups during the study. Patton (1990) suggests selecting information rich cases to obtain in-depth information from sample. On the other hand, the researcher and the course instructor assigned the groups such that each group was homogeneous in terms of academic success, group working and technical skills. Researcher could get information from the survey which proposed to collect information about students' collaborative working skills, pre-knowledge on programming and academic success. To make deep observations and interviews, the researcher selected 17 students ( 5 project teams) for the first project and 9 students (3 teams) for the second project. Randomly selection procedure was used for the first project teams because the facilitator did not know the students and already all the teams were consisting of the students having different skills and competencies. In the second project a purposive selection was implemented. At the end of the semester, the researcher conducted individual interviews with 20 voluntary students ( 9 females and 11 males).

Apart from the current students of the course, the researcher also conducted interviews with previous years' students to triangulate data and to see the outcomes of the course. 10 of the participants were the previous year's students. Since the course was not different than the last year's course, the researcher aimed to understand awareness of experience of those students. Another 16 participants were graduated in different years, all of them took the same course but there were some differences in the tools that were used and the activities. However, since the method was not changed, the researcher wanted to triangulate "outcomes" of the instructional design practice by using current students and graduates. Gender and sample distribution of the study can be seen on Table 2.

Table 2. Gender and sample distribution of interviewed students

\begin{tabular}{lccc}
\hline Gender & $\begin{array}{c}\text { Current students } \\
\text { (CS) }\end{array}$ & $\begin{array}{c}\text { Previous students } \\
\text { (PS) }\end{array}$ & Graduates (GS) \\
\hline Female & 9 & 4 & 10 \\
Male & 11 & 6 & 6 \\
\hline Total & 20 & 10 & 16 \\
\hline
\end{tabular}

\section{ACTIVITIES OF THE SEMESTER}

The study was proposed to take fifteen weeks, students came to classroom for two hours then they attended one hour meetings with the researcher and other facilitators. For the first six weeks, students took two-hour computer lab sessions. In lecture part attendance was not mandatory but facilitator meetings and lab sessions were mandatory. The semester was divided into two parts; in the first part students developed interactive multimedia to teach a concept via and in the second they developed a 5minute procedure teaching video. For both projects students followed ADDIE instructional design model consisting analysis (learner, content, context, need), design (storyboarding), development (technical aspect), implementation (to target group) and evaluation. For the first project, instructor created homogenous groups based on their technical and social skills.

As seen on grading Table 3 concept teaching part covered $40 \%$ of the total scores. There were a lot of deliverables which students get scores. Only totally 20 points is based on individual work. 
Table 3. Grading table of the course

\begin{tabular}{lcccc}
\hline Deliverable & $\begin{array}{c}\mathbf{1}^{\text {st }} \\
\text { project }\end{array}$ & $\begin{array}{c}\mathbf{2}^{\text {nd }} \\
\text { project }\end{array}$ & $\begin{array}{c}\text { Lab } \\
\text { assignments }\end{array}$ & Total \\
\hline Group contract & 2 & & - & \\
Analysis Report(required to proceed) & 5 & 5 & - & \\
Design Report(required to proceed) & 5 & 5 & - & \\
Instructional Materials & 13 & 13 & - & \\
Project Report & 10 & 10 & - & \\
Peer reviews & 5 & 1 & - & \\
Presentation & - & 6 & - & \\
Individual work & 40 & 4 & 15 & 100 \\
\hline Total & & & & \\
\hline
\end{tabular}

For the procedure teaching project, the processes were very similar. However, at that time students were free to form their groups and the researcher took three groups among 15 groups, thus each facilitator took equal number of groups in the second project. This time student was expected to prepare a five-minute video to show a procedural topic. In the first week students were taught a video editing software in the lab, but they were free to use any other video editing programs. After the first, two week of procedure teaching project, class lectures were ended, but weekly meetings continued. In the first week of the project, groups also signed their contract and submitted to their facilitators. During procedure learning project, their questions on reports or the project was much less than the first project. In procedure learning project students were supposed to prepare a video as group and a manual for the video individually. By doing this, instructors and facilitators wanted to understand to what extent students get visual design principles. Meanwhile, the researcher interviewed graduates and the students who took the course previous year. The students who participated in this study were interviewed in the last two weeks of the semester.

On the final day, before presentations post-questionnaires were distributed and collected. Students submitted their reports and manuals, and presented their videos on the final examination date of the course. On that day, each group was given totally 13 minutes to present their progresses and show the 5-minute video. While they were presenting, all the facilitators and instructors scored students' performance by using a template, each student was given different scores. After presentation, students again sent their peer evaluations.

Shortly, in the course there were mainly four activities in the course, lecture times, lab hours, facilitator meetings and target group meetings (See Figure 1). In the first project phase each week lectures and lab hours were conducted while in the second project there lasted soon. In both processes while designing and developing the materials same instructional design model was used. 


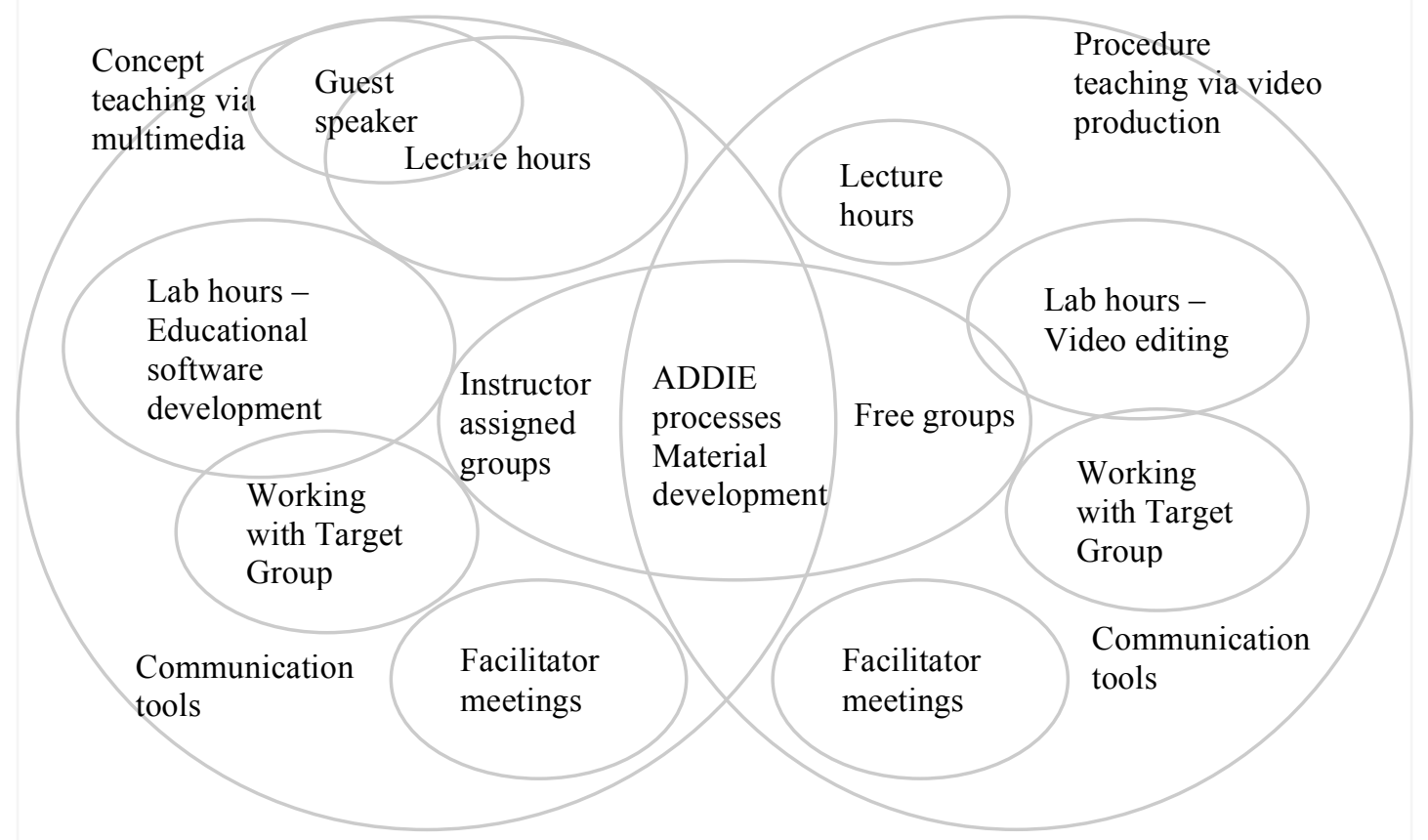

Figure 1 Representation of course context

In the first project while students worked as randomly assigned groups in the second one they selected their group members. For both project students used different communication channels to communicate with facilitators, target groups, lab assistants and instructor.

\section{DATA COLLECTION INSTRUMENTS}

Main data collection instruments of the study were classroom observations, sound records of weekly meetings, personal interviews and several pre and post activities. The details are given below.

\section{RECORDS OF WEEKLY MEETINGS}

Each week the researcher talked with students about the instructional design issues, visual design, technical issues, group problems, how they overcame problems and requirements the next steps. She arranged meeting hours and each group was given about 15 minutes to talk about their projects. In these meetings the researcher had a chance to understand community issues, challenges of the students, their characteristics, habits, progresses in the project and their improvement during the semester. Researcher recorded the meetings with a sound recorder to triangulate the whole data. The researcher met with concept project groups 8 times and procedure project groups 6 times. Totally 47 group meetings were conducted and 37 of them were recorded with sound recorder. Remaining meetings were excluded since they were very short meetings. In fact, some groups did not want to come to some of the meetings mostly because they did not have any progress in a specific week. The researcher also took some notes about individual students and general overview of the work.

\section{INTERVIEWS}

Students were individually interviewed about their experiences on the course, what difficulties they have, what they like about the course, what they have learned by designing a multimedia and what they experienced related to instructional design. Interview schedule was prepared by the help of an expert researcher and it was piloted with six students in a multimedia design development course which was given in the same way with multimedia development course. There were 12 main questions and 2 or 3 prompts under the questions for all three groups. All the participants were voluntary. Researcher also invited previous year's students in person and in that time information rich cases were selected. For the current students, the researcher sent invitations to the entire student body and she interviewed all the volunteers. Interviews took 19 minutes on average for each student. 
Interviews took 26.4 minutes on average for each graduate, 21.0 minutes for each of the student who took the course a year before and, 19.3 minutes for the students who were the actual participants of the study. After transcribing the entire interview records the researcher digitally coded and analyzed them.

\section{PRE AND POST QUESTIONNAIRE}

Students were given a background questionnaire that consists of short open ended questions and several likert-type questions related instructional design skills. 31 of the current students took both pre and post questionnaire. Open ended questions were related their pre-knowledge and past experiences related instructional design such as group working habits, students' roles in group working, and their preferences about material development. The rating questions were modified version of instructional designer skills which were suggested by Richey, Fields and Foxon (2001). Researcher did very little modification and she excluded some titles which are not in the scope of the course. Students rated themselves in terms of 24 main instructional designers' skills. Scale was from 1 to 5 where 1 means very poor and 5 means very good. Researcher applied the questionnaire at the beginning of the semester and the Final day. She made qualitative content analysis for open ended questions and she compared the mean scores of participants' responses to the scale. The results were used to triangulate students' responses in the interviews.

\section{DATA ANALYSIS}

Questionnaire and interview data were coded and frequencies of them were reported. Quantitative data in the pre and post questionnaire were compared with Paired Sample T-Test. The researcher improved her instruments by taking the pilot study students' reactions into consideration. The researcher coded and analyzed the data with another researcher who is experienced with the course and qualitative studies. In the pilot study the inter-reliability of the data was like below (see Table 4).

Table 4. Inter-reliability scores of each instrument

\begin{tabular}{lc}
\hline Type of the data & Percentage of agreement \\
\hline Questionnaire & .82 \\
Group interviews & .83 \\
Individual interviews & .83 \\
\hline
\end{tabular}

With this high score of inter-reliability, researcher also made decisions on the method of collection and analysis data. For example, in the pilot study the ID activity was given to the teams and there was only one solution. It made difficult to interpret the improvement of the individuals.

\section{FINDINGS}

As outcome of the multimedia design projects, instructional design skills of novice instructional designers were revealed.

\section{INSTRUCTIONAL DESIGN OUTCOMES}

In the course many instructional design skills were proposed to be gained by the students. The goals of the course were mainly related the employ an instructional design and development process for a target group. Main categories might be grouped as awareness of ID processes, knowledge on ADDIE model, analysis and synthesize of information taken from target group, design of instruction, message design, storyboarding, using computer based development tools, evaluation of instruction, team working and project management, and ethical issues.

As mentioned before the researcher used competency definitions of IBSTPI by considering the course's competency objectives and asked students grade themselves in terms of these competencies. In the pre and post questionnaires students scored their competencies from 1 point to 5 . The expected outcomes of the system were listed as shown in Table 5.

Table 5. Pre and post perceived instructional design competencies

\begin{tabular}{lccc}
\hline & $\begin{array}{c}\text { Pre- } \\
\text { Questionnaire }\end{array}$ & $\begin{array}{c}\text { Post- } \\
\text { Questionnaire }\end{array}$ & $\begin{array}{c}\text { Difference } \\
\text { (p) }\end{array}$ \\
\hline Knowledge of instructional technologies & 3.4 & 3.8 &, 000
\end{tabular}




\begin{tabular}{llll} 
Conducting instructional design processes & 3.0 & 3.6 &, 000 \\
$\begin{array}{l}\text { Development of storyboards } \\
\text { Using multimedia development programs }\end{array}$ & 3.1 & 3.9 &, 000 \\
Assessment of instructional materials & 3.2 & 3.8 &, 001 \\
$\begin{array}{l}\text { Effective use of technological resources for } \\
\text { instruction }\end{array}$ & 3.0 & 3.6 &, 002 \\
Conducting and reporting research & 3.4 & 4.0 &, 003 \\
Audio/video editing & 3.1 & 3.8 &, 006 \\
Working collaboratively in teamwork & 3.3 & 3.6 &, 016 \\
Hardware knowledge & 4.0 & 4.2 &, 022 \\
Using image editing programs & 3.5 & 3.7 &, 031 \\
Working under supervision & 3.5 & 3.7 &, 083 \\
Knowledge of usability issues & 3.5 & 3.8 &, 148 \\
Improving pedagogical knowledge & 3.4 & 3.7 &, 166 \\
Content development & 2.9 & 3.2 &, 170 \\
Improvement of communication and organization & 3.4 & 3.6 &, 247 \\
skills & 3.9 & 4.1 &, 345 \\
Interaction with other cultures and communities & 3.5 & 3.8 &, 425 \\
Project management & 3.7 & 3.8 &, 523 \\
Consulting and supporting others & 3.8 & 3.9 &, 678 \\
\hline
\end{tabular}

As shown in Table 5, skills related knowledge on instructional technologies, instructional design process, storyboarding, using multimedia development programs, assessment of instructional materials, effective use of technological resources, conduction and reporting of research, audiovisual editing, collaborative work and knowledge hardware there was a significant improvement among students. The qualitative analysis of interviews revealed some outcomes which are parallel with the objectives of the course. The outcomes which were mentioned by the students are listed in Table 6 .

Table 6 . Frequency of the outcomes which were mentioned by NIDs

\begin{tabular}{lccc}
\hline Skills & $\begin{array}{c}\text { Current } \\
\text { Students }\end{array}$ & Graduates & $\begin{array}{c}\text { Previous } \\
\text { Students }\end{array}$ \\
\hline Awarenes of importance and process of ID & 17 & 6 & 4 \\
Technical skills (Learning development tools) & 16 & 1 & 6 \\
Team working skills & 12 & 7 & 3 \\
Research and reporting the processes & 9 & 7 & - \\
Real life experience & 6 & 1 & - \\
Project management & 6 & 1 & 1 \\
Storyboarding (message and content design) & 5 & 2 & 2 \\
Communication with target group & 4 & - & - \\
\hline
\end{tabular}

As seen in Table 5, NIDs mainly mentioned about understanding ID process, learning the development tool, reporting and team working. On the other hand, not all that issues mentioned in a positive way. For example, for the development tool, 3 of the students stated that they had difficulty in learning development tool. For reporting some of the students complained about strict templates and difficulty in writing some parts of the reports. However, there were several reasons triggering this kind of negative attitudes. Another issue was problem with evaluation phase of ID. Since the project periods were short, students could not find enough time to evaluate their project with real target groups. However, they stated that they made usability tests of the projects with experts.

The combination of outcomes which were mentioned by graduates and previous year students can be listed as "project management, learning ID process, working under supervision, reporting, material evaluation - usability, team work, message design, technical skills, video recording process, video editing process, understanding target group, time management and visual design". Although the researcher does not argue that it is directly related to the course, the graduates also associated the 
course with the skills of "project management, message design, step by step process, guiding colleagues, reporting, technical skills and tool analysis" which they are using in their current jobs. Since, after the course the students get more ID design related courses, it is difficult to find a direct connection with the learning outcomes which are used in the jobs.

When combining, course objectives which are also evoked from IBSTPI competencies and the outcomes mentioned by the participants, the researcher clarified the main themes. The main outcome categories are shown in Table 7.

Table 7 Main competency themes and sub issues

\begin{tabular}{|c|c|}
\hline Main category & Sub issues \\
\hline \multirow{5}{*}{$\begin{array}{l}\text { Awarenes of importance and } \\
\text { process of ID }\end{array}$} & Learning analysis process \\
\hline & ADDIE model \\
\hline & Learning planning process \\
\hline & Learning step by step processes \\
\hline & Learning about evaluation \\
\hline \multirow{6}{*}{$\begin{array}{l}\text { Technical skills (Learning about } \\
\text { development tool) }\end{array}$} & Overcoming challenges in using development tools \\
\hline & Using development tool effectively \\
\hline & Overcoming challenges in video recording and editing \\
\hline & Understanding video production process \\
\hline & Learning procedure teaching \\
\hline & Using video editing tools \\
\hline \multirow[t]{5}{*}{ Team working skills } & Solving team problems \\
\hline & Defining and implementing team work rules \\
\hline & Learning to work with different people \\
\hline & Developing ideas with different people \\
\hline & Guiding the team \\
\hline \multirow{4}{*}{$\begin{array}{l}\text { Research and reporting the } \\
\text { processes }\end{array}$} & Knowing what to write in report template \\
\hline & $\begin{array}{l}\text { Synthesizing information obtained from different } \\
\text { resources }\end{array}$ \\
\hline & Being comfortable in reporting \\
\hline & Overcoming challenges in writing report \\
\hline \multirow[t]{4}{*}{ Real life experience } & $\begin{array}{l}\text { Understanding that some processes in the course is } \\
\text { similar with real projects }\end{array}$ \\
\hline & Working with a real target group \\
\hline & Working in a school which represents the whole country \\
\hline & Feeling of working in a real project \\
\hline \multirow[t]{4}{*}{ Project management } & Time management issues \\
\hline & Leadership in the team \\
\hline & Monitoring the team work \\
\hline & Planning and dividing the processes \\
\hline \multirow{11}{*}{$\begin{array}{l}\text { Storyboarding (message and } \\
\text { content design) }\end{array}$} & Visual design \\
\hline & Task analysis \\
\hline & Using target group information to design \\
\hline & Usability issues \\
\hline & Selecting suitable approaches and methods to design \\
\hline & Selecting visuals \\
\hline & Selecting characters and story \\
\hline & Understanding the importance of storyboarding \\
\hline & Change in perception of storyboarding \\
\hline & Understanding what a storyboard is \\
\hline & Creating detailed storyboard \\
\hline
\end{tabular}


Searching actual content

Creating content by using textbooks

Creating visuals - animations

Being subject matter expert in the project

Communication with target Learner analysis

group

Synthesis of target group information

Communication with target group teacher

Implementation of target group expectations

According to Table 7, students experienced many issues. However, this does not necessarily mean that they expertise on them as mentioned previous paragraphs.

\section{DISCUSSION}

In terms of students' ID experience, their ID process awareness and practices, real context experience, target group interaction, team work and project management, message design, content development, research and reporting skills, learning and using development software were examined. In the course, both ID and multimedia design experience was given. Novice instructional designers can show a better performance if they become conscious about the process that they practice instructional design (Jonassen \& Murphy, 1999). In fact, many of the students came to class being unaware of the processes. Then they became aware of some processes continuing step by step, however most of them challenged to elaborate the previous step to the next step. This result is exactly similar with the results revealed in Hardre, Ge and Thomas (2006) in which authors explored that novice instructional designers treated the phases of ID like very different parts while after getting experienced they started to look ID phases as holistic process (p. 81). Moreover, they revealed that perception of responsibilities of instructional designers and metacognitive skills influence to expertise ID. Shortly, novice instructional designers should become aware of their responsibilities, their experiences, their skills, their weaknesses and strengths to grasp the ID processes well.

In practicing ID also NIDs had difficulty towards the end. They started with good analysis process, and design process was also complete. On the other hand, most of them could not practice formative and summative evaluation because of lack of time and lack of motivated target group. In fact, these issues are available in the real context. Holcomb et al. posed that instructional designers do not go through all the steps which was required in traditional ID model. Holcomb, Wedman and Tessmer (1996)'s study which researchers inquired 40 experienced instructional designers about their 77 instructional design projects, showed that instructional designers stated that in $95 \%$ of their work they thoroughly defined the objectives of the instruction and in $92 \%$ of them, they selected instructional strategies. On the other hand, in only $34 \%$ of the projects, they implemented a summative evaluation at the end of the implementation. Although the context might be different, in this study also there was problem of implementation of summative evaluation. In this context, one of the reasons was that there is not enough time to conduct an evaluation. On the other hand, in some groups although they got feedback from target group teacher, students did not improve their project since the project was already graded.

Most of students came to class knowing that they will make two projects and they would work as random groups in the first project. On the other hand, they were not aware of processes which they would go through while developing materials. Most of students especially males focused on technical skills which provide potential of working in a company. Therefore, first of all, this unawareness of what ID is being the problem in the context. As pointed in several places, each student's awareness and perception on their experience was different in accordance with their expectations and motivations. The students who wanted to learn about development software disappointed because they wanted very intense practice of development tool, while some of them satisfied because they tended to improve themselves. 
Motivations and expectations of students also caused perceive ID experience differently. While some of the students became aware of ID processes, some of them just see them as "boring reporting process" or some of them called it as "deeply analysis and planning process" by ignoring formative and summative evaluations. In fact, students became aware of "project management process" rather than ID processes. In other words, step by step processes were realized however, they neither could connect all phases consistently nor they practice each requirements of ID properly. To develop ID expertise of students, they should be told about expected competencies clearly, thus they could "develop realistic self-perceptions" (Hardre, et el, 2006, p. 85).

As a second issue, as undergraduate students, they needed to assistance to conduct teamwork especially when they work with a friend which they have never worked together before. Teamwork is one of the most important skills for instructional designers. Although most of students implied that random grouping was beneficial to experience coping with different people and different styles, in practice they did not tend to solve problems in the group. Even though some students saw that the processes are like real company's work policies, in team working they could apply any real life strategies. This might be caused that in random groups; students did not want to deal with someone who they did not know well. Because of lack of sympathy between group members they might not want to tolerate others in some cases as well.

Instructional design project requires considerable time to make a wide sense analysis and design. In this course context for facilitators and students time was not enough to grasp all ID steps and apply them properly. On the other hand, since natures of two projects were different, it enrichened their experience. They worked with different facilitators, target groups, different tools and different team members. NIDs could make comparison between two experiences. It was accepted that the second project was much more comfortable not only because of previous experience but also working with bellowed friends. Moreover, video project required less technical skills than developing multimedia instruction.

Although in real life each person's role is different in this context students were expected to work in each phase equally. Students had to develop their project by themselves. This issue caused several troubles. Firstly, technical skill requirement led students think that their actual role is to develop most attractive and technically advance things. Secondly, since students had very short time to improve them technically, students ignored most of ID processes. Lastly, it caused such a division of labor that technically skilled students focused on development and others focused on ID processes. In this context it is not possible to provide all real context issues like providing programmers who develop students' designs. Besides, group members are not skilled programmers, reporters, animators and graphic designers at the same time. According to Goodyear (1997) for an efficient task sharing all instructional design team should have similar skills. Since this is not possible in an undergraduate course, at least students should be asked to monitor others' work to get some experience from them. Again, they should be reminded of the importance of the processes of ID, more than the importance end product. In this case, the technical requirements might be reduced in some extent for this course. Thus, students might pay attention to analysis and design processes more.

Working with a client was difficult in the course content. In fact, this issue is a challenge in each instructional design project (Gibby, Quiros, Demps \& Liu, 2002). Working with a target group was important issue, however, because of lack of monitoring of facilitators and instructor, most of project groups they could not work with target group properly. In this context also target group communication was not like in the real world. In real settings, target group brought their needs to instructional designer, specify all expectations. On the other hand, in this context project groups selected a topic at the beginning, and they tried to find a target group to get their opinions about the topic. Most of time, those target group people only helped students in analysis stage. Because of policies of the schools it was not easy to implement those projects in the classes. Moreover, because of lack of infrastructure, that target group teachers had no chance to implement the projects. Yet, most of them even did not consider those projects to implement in their class. Since students were undergraduate students, teachers might not have regarded those projects as usable projects. For all 
these issues, instructors and facilitator might have played a key role in providing effective communication between target group and the students. With required permissions students should be given chance to enter the schools and work with teachers. On the other hand, in this term, motivation of target group is also very important. In this case although target group teachers were very open to give information about their context, most of them did not consider implementing those projects. Students also could not set up a good connection with target group.

Although it was suggested that target group should be arranged by instructor, it might not be the exact solution. For instance, in the second project although target groups were very convenient, like being in the first project, students could not conduct formative evaluations properly. Again lacks of time caused them both design and evaluate the instruction at the same time. Moreover, students lack of background experience with working with a target group, prevent effective work with them. Since they were not aware of their further processes at the beginning, they did not get any promise from target group to implement their projects. Furthermore, for students it is almost impossible to work with actual learners, most of time they could only contact with a teacher. Although the teachers might be assumed as knowledgeable about their students, still students could not grasp what the learners really need to learn and how they want to learn. This problem is not much different than what happened in real project. Goodyear (1997) also points out this issue and he stated that most of time instructional designers could not reach target learners easily and their contact person do not understand what the learners need in fact.

Certainly very few groups could work with a target group effectively. On the other hand, in even that case they applied what the target group asked them even though their expectations sometimes reduce the effectiveness and quality of instruction. Lack of interaction with target group caused some challenge like developing a content which is most suitable for the target students and exploring misconceptions and characteristics of the target students. Thus, in instructional design team students' roles increased. According to Keppell (1999) instructional designers should work on as much as cases to improve the content development skill and accelerate the development of ideas for content production process. In his study which seek instructional designer and subject matter interaction, he also revealed that creation of knowledge maps were very helpful to understand the unfamiliar topics. In this case target group did not know what the student projects would look like, therefore some of them tended to speak about their general technology needs instead of focusing on multimedia development. If instructors and facilitators would accompany students in their target group visit this issue might have been solved.

In project management NIDs could not apply a good leadership role in unexpected problems. Although they selected females as leaders since they believed their organization skills are good, in a time the roles changed and the member who is academically or technically dominant became the decision maker and leader of the projects. Especially in the first projects facilitators had to behave like project leader. Facilitators had to remind them to go target group, ask specific questions, draw a storyboard, and send their draft work although all schedule was given at the beginning of the course and in report templates all requirements were stated. After this reminds group leader's role was to bring group members together and share the work. In fact, this was a natural consequence of the course because students had no practical ID experience. They needed facilitator's guidance to start and finish the processes. Another issue, in the first project especially, NIDs did not select their team members, on the other hand after assignment of the groups, each team member tended to select their role. The groups who share all the work, on the other hand, expected all members start and finish the work at the same time. Lastly, leader students getting more responsibility and in an undergraduate context, with the concern of grading, students could not spend much time deal with making others work smoothly. The leader students developed different strategies which led them finish the work quickly and easily. Shortly, in each group project management was implemented in different way but commonly they focused on finishing deliverables in time.

It was not possible to give a project management skill in addition to many new learning situations in the course. However, it should be emphasized that project management including communication, 
leadership, supervising skills should be one of the major parts of instructional design curriculum (van Rooij, 2010). With new curriculum of CEIT, project management became two semester course given to senior students. However, it might be a bit late to offer this course after this kind of instructional design courses. Moreover, as a research assistant of those project management courses, again software development become dominant because all students focus on finishing their tasks in time while they are also busy with other commitments. Furthermore, it seems senior students still do not want to deal with analysis and planning processes. Recently, a senior student who is taking project management course complained about they spent too much time in planning phase and it made them lose much time. With this respect, one of the most important precautions might be leading students understand the importance of the pre-analyses and processes during the planning stages.

Generally speaking, this undergraduate course was not enough (and not expected) to provide expertise to students, since very complex instructional design skills were tried to be given in a very short time. On the other hand, at least they could experience as many issues of ID. It can be suggested that their skills should be strengthening in further courses and practices. Another suggestion might be reducing the project numbers, providing a convenient target group and letting students reflect their experience in each phase of design. To evoke the awareness of ID progresses, reflections might be used to make them aware of each step that they go through (Tracey, Hutchinson \& Grzebyk, 2014). At the end part of each report, NIDs reflection about the processes of ID and their reflections on their experience might be asked. During meetings, reflections of the students might be inquired by facilitators. In this case misconception of students might be removed just in time.

\section{REFERENCES}

Bannan-Ritland, B. (2001). Teaching Instructional Design: An Action Learning Approach. Performance Improvement Quarterly, 14(2), 37-52.

Barron, B. J. S., Schwartz, D. L., Vye, N. J., Moore, A., Petrosino, A., Zech, L., \& Bransford, D. J. (1998). Doing with understanding: Lessons from research on problem and project-based learning. The Journal of the Learning Sciences , 7(3), 271-311.

Bratton, B. (2007). Professional Competencies in the Instructional Technology Field. Trends and issues in instructional design and technology. Reiser, R.A., \& Dempsey, J.A. (Eds.). Upper Saddle River, New Jersey : Merrill/Prentice Hall.

Dabbagh, N. \& Bannan-Ritland, B. (2005). Online learning: Concepts, strategies, and application.Upper Saddle River, NJ: Prentice Hall, Pearson Education.

Dabbagh, N. \& Blijd, C.W. (2010). Students' Perceptions of Their Learning Experiences in an Authentic Instructional Design Context, The Interdisciplinary Journal of Problem-based Learning , 4(1), 6-29.

Davidson - Shivers, G.V. \& Rasmussen, K. L. (2007). Competencies for Instructional Design and Technology Professionals. In Reiser, R.A., \& Dempsey, J. A. (Eds.). Trends and issues in instructional design and technology (pp.271-286). Upper Saddle River, NJ: Merrill/Prentice Hall.

Gayeski, D. M. (1993). Multimedia for Learning: Development, application, evaluation. Emglewood Cliffs, NJ: Educational Technology Publications.

Gergen, K. J. (1985). The Social Constructions Movement in Modern Psychology, 40(3), 266-275.

Gibby, S., Quiros, O., Demps, E. \& Liu, M. (2002). Challenges of Being an Instructional Designer for New Media Development: A View from the Practitioners. Journal of Educational Multimedia and Hypermedia, 11(3), 195-219. Norfolk, VA: AACE.

Gifford, B. R. Enyedy, N.D. (1999). Activity centered Design: Towards a theoretical framework for CSCL. In Proceeding the CSCL'99 conference (pp 189-197), December 12-15.

Gustafson, K. (2002). Instructional design tools: A critique and projections for the future. Educational Technology Research and Development, 50(4), 59-66.

Goodyear, P. (1997). Instructional design environments: Methods and tools for the design of complex instructional systems. In S. Dijkstra, N. M. Seel, F. Schott, \& R. D. Tennyson, (Eds.), Instructional design: International perspectives (pp. 83-111). Hillsdale, NJ: Lawrence Erlbaum.

Gustafson, K. L. \& Branch, R. M: (2007). What is Instructional Design? (Ch. 2). Reiser, R.A., \& Dempsey, J.A. (Eds.). Upper Saddle River, New Jersey : Merrill/Prentice Hall. 
Holcomb, C., Wedman, J.F. \& Tessmer, M. (1996). ID Activities and Project Success: Perceptions of Practitioners, Performance Improvement Quarterly, 9(1), 49-61.

Jonassen, D.H. \& Rohrer-Murphy, L. (1999). Activity theory as a framework for designing constructivist learning environments. ETR\&D, 47(1), 61-79.

Kafai, Y. (1995). Minds in play: Computer game design as a context for children's learning. Mahwah, NJ: Lawrence Erlbaum.

Keppell, M. (1999). The Crucial Roles of the Instructional Designer and the Subject Matter Expert in Multimedia Design. In B. Collis \& R. Oliver (Eds.), Proceedings of World Conference on Educational Multimedia, Hypermedia and Telecommunications 1999 (598-603). Chesapeake, VA: AACE.

Papert, S. \& Harel, I. (1991). Constructionism. Norwood, NJ: Ablex Publishing.

Patton, M.Q. (1990). Qualitative Evaluation and Research Methods. NewBurry Park, CA: Sage.

Hardre, P. L., Ge, X. \& Thomas, M. K. (2006). An Investigation of Development Toward Instructional Design Expertise, Performance Improvement Quarterly, 19(4), 63-90.

Liu, M. \& Rutledge, K. (1996). The Effect of a "Learner as Multimedia Designer" Environment on At-Risk High School Students' Motivation and Learning of Design Knowledge. Paper presented at the Annual Meeting of the American Educational Research Association, New York, NY, April 8-12.

Rasmussen, K. L. (2002). Competence at a glance: Professional Knowledge, skills and abilities in the field of instructional design and technology. In Reiser, R.A., \& Dempsey, J. A. (Eds.). Trends and issues in instructional design and technology (pp.375-385). Upper Saddle River, NJ: Merrill/Prentice Hall.

Reiser, R.A. (2001). A History of Instructional Design and Technology: Part I: A History of Instructional Media, Educational Technology Research and Development, 49(1), 53-64.

Reiser, R.A. (2007). What field did you say you were in? Defining and naming our field. Ch 1 in Trends and issues in instructional design and technology. Reiser, R.A., \& Dempsey, J.A. (Eds.). Upper Saddle River, New Jersey : Merrill/Prentice Hall.

Richey, R., Fields, D.C. \& Foxon, M.(2001). Instructional Design Competencies: The Standarts, Sycrause, NY: ERIC Clearinghouse on Information and Technology.

Rowland, G., Parra, M.L., \& Basnet, K. (1995). Educating instructional designers: Different methods for different outcomes. In Seels, B.B. (Ed.). Instructional design fundamentals: A reconsideration. (pp.223-235) Englewood Cliffs, NJ: Educational Technology Publications.

Seels, B. (1995). Instructional Design Fundamentals: A Reconsideration. Englewood Cliffs, NJ: Educational Technology Publications.

Sherry, L., \& Myers, K.M. (1998). The dynamics of collaborative design. IEEE Transactions on Professional Communication, 41(2), 123-139.

Spector, M. (2001). Glossary of IBSTPI Instructional Design Terms. In Richey, R., Fields, D.C. \& Foxon, M.(Eds). Instructional Design Competencies: The Standarts (pp. 179 - 184), Sycrause, NY: ERIC Clearinghouse on Information and Technology.

Sugar, W. A. (2001). What is so good about user-centered design? Documenting the effect of usability sessions on novice software designers. Journal of Research on Computing in Education, $33(3), 235-250$.

Tessmer, M., \& Richey, R. C. (1997). The role of context in learning and instructional design. Educational Technology Research \& Development, 45(2), 85-115.

Tracey, M. W., \& Baaki, J. (2014). Design, Designers and Reflection-in-Action. In B. Hokanson \& A. Gibbons (Eds.), Design in educational technology: Design thinking, design process, and the design studio (pp. 1-13). New York: Springer

Tracey, M. W., Hutchinson, A., \& Grzebyk, T. Q. (2014). Instructional designers as reflective practitioners: Developing professional identity through reflection. Educational Technology Research and Development, 62(3), 315-334.

Van Rooij, S. W. (2010). Project management in instructional design: ADDIE is not enough. British Journal of Educational Technology, 41(5), 852-864.

Visscher-Voerman, I., Kuiper, W., \& Verhagen, P. (2007). Educating educational designers: The university of twente case. In M. Simonson (Ed.), Proceedings of the Association for Educational Communications and Technology (2nd ed., pp. 332-343). Anaheim, CA: AECT. 
Winn, W. (1997). Advantages of a theory based curriculum in instructional technology. Educational Technology, 37(1), 34-41.

York, C. S., Ertmer, P.A. \& Gedik, N. (2009). Extracting Heuristics from Expert Instructional Designers, In Simonson, M. R. (Ed.) 32nd Proceedings of Association for Educational Communications and Technology. (pp. 496- 510). Louisville, KY.

Young, R. A. \& Collin, A. (2004). Introduction: Constructivism and social constructionism in the career field, Journal of Vocational Behavior, 64(3), 373-388.

Yusop, F. D., \& Correia, A. (2012). The civic-minded instructional designers framework: An alternative approach to contemporary instructional designers' education in higher education. British Journal of Educational Technology, 43(2), 180-190. 